\title{
A New Virus Disease of Papaya (Carica papaya) in Puerto Rico ${ }^{1}$
}

\author{
José Adsuar'²
}

\section{INTRODUCTION}

Bunchy top and mosaic diseases of papaya (Carica papaya) have been reported from various tropical and semi-tropical regions of the world. Evidence obtained recently indicates that the causal agent of bunchy top may be a mycoplasma-like organism (1). This opinion is based upon the response of bunchy top-infected papaya plants to selected antibiotics and to the occurrence of mycoplasma-like bodies in sections of infected phloem parenchyma and sieve tubes.

Bunchy top and Puerto Rican southern coast papaya mosaic are destructive diseases of papaya in Pucrto Rico. Bunchy top (2) causes stunting, and also yellowing and stiffening of the canopy of affected plants. On wounding or pricking, latex fails to flow from affected plant tissues. Puerto Rican southern coast papaya mostic is characterized by mottling, extreme distortion and restrietion of the leaf laminae and by the presence of green and brown rings on the fruit. However, latex flows freely from mosaic-affected plants.

The Puerto Rican southern enast papaya mosaic virus has been studied extensively at the Agricultural Experiment Station of the University of Puerto Rico $(3,4,5)$. A virulent new mosaic disease of papaya (fig. 1) appeared in the northern coast of the Island near the town of Isabela. The role played by various aphids in the transmission of this new mosaic, as well as in the transmission of the l'uerto Rican southern coast papaya mosaic, was studied by Schacfers (6). The Isabela mosaic is threatening established commercial ficlds and future expansion of papaya culture in that area.

The present paper deals with the nature, physical properties and host range of the causal agent of this new mosaic disease of papaya.

\section{MATEIRIALS AND METHODS}

Experimental plants were grown and maintained in the greenhouse. Local papaya seeds wore obtained from the Station's P'ant Breeding Department. Test plants were grown in (6-inch pots and sprayed periodically with various insecticides as a precautionary measure. Young papaya

1 Mantseript submitted to liditorial Boatd May 16, 1972.

2 Phỵlopathologist, Agricultural Fxperiment Station, Mayagüez Campus, University of Puerto Rico, Rion Piedras, P.R. 


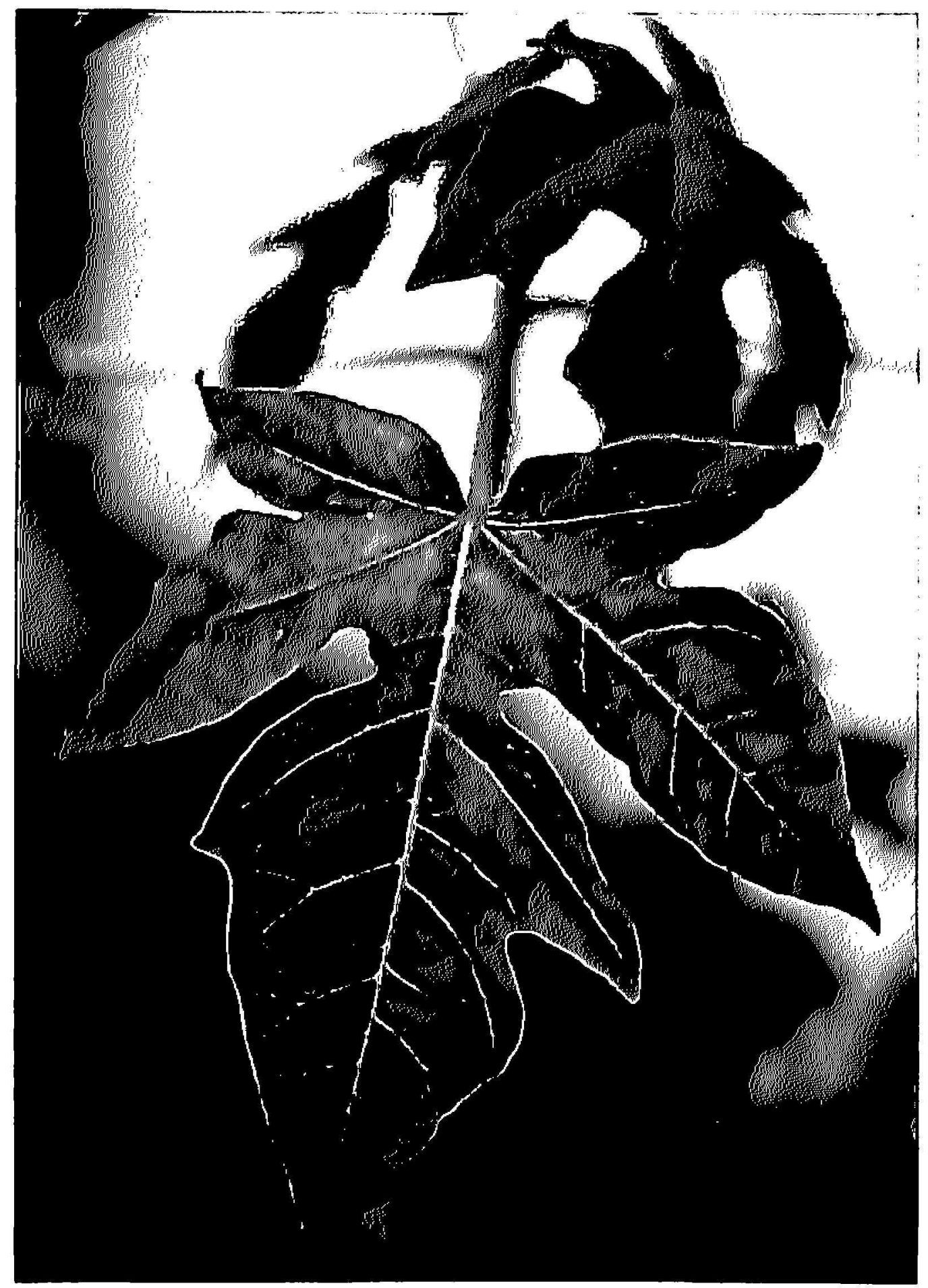

Fig. 1. Symptoms of Isabela mosacic on young papaya plant leaf.

plants were dusted with (arborundum (400 mosh) and then inoculated by rubbing with a cotton swab impregnated with infectious juice. The same procedure was followed when plants other than papaya were inoculated.

For studies on thermal inartivation, expressed sap (1 ce. in each rase) from a discased plant was poured into a thin-malled vial. The vial was 
capped and treated at the desired temperature, in a constant temperature electric water bath, for 10 minutes. The vials were cooled in tap water and the saps used immediately for inoculation. Freshly extracted juice from mosaic infected plants was used for studies on dilution end-point. The juice was diluted with sterile distilled water. Longevity in vitro was determined by leaving undiluted infectious juice at laboratory temperature (about $20^{\circ} \mathrm{C}$.) and testing for infectivity at different time intervals.

For soil transmission studies, healthy papaya seedlings were transplanted to pots containing infected papaya plants. The infected papaya plants were cut down at soil level a few days after the healthy seedlings were planted.

For seed transmission tests, seeds from infected papaya trees showing clear mosaic symptoms were planted in flats. The resulting seedlings were observed daily for at least 2 months.

The role played by the nematode Trichodorus christiei in the transmission of the causal agent was also studied. Healthy and mosaic infected papaya seedlings were grown together in 6-inch pots containing sterilized soil. The nematode under study was then added to each pot in $1 \mathrm{ml}$. of distilled water at the rate of 150 individuals per milliliter. Check pots were treated with sterile distilled water only. The treated and control plants were observed for periods of 2 or more months.

Studies on cross protection between the Isabela mosaic and the Puerto Rican southern coast papaya mosaic viruses were undertaken by first inoculating with the mild mottling Isabela mosaic virus and then reinoculating with the more virulent leaf-distorting Puerto Rican southern coast papaya mosaic virus.

\section{RESULTS}

Inoculated papaya plants showed vein clearing of new leaves in about 10 to 15 days. These symptoms were followed by yellow mottling, without evident leaf distortion. Oily spots were formed along stems and latex flowed freely when stems or leaves were punctured.

The Puerto Rican southern coast papaya mosaic virus differs from the Isabela mosaic virus in that the former causes extreme deformation of the leaves. Most Isabela farms inspected were affected with the Isabela mosaic virus, although Puerto Rican southern coast papaya mosaic also was observed. Mixed infections were common.

The Isabela mosaic virus was transmitted by mechanical means to the following plants: Cucumis sativus var. Black Diamond, Cucumis melo var. Fortuna, Citrullus citrullus var. Cannon Ball, Siceria lagenaria, Cucurbita pepo var. Early Prolific Straightneck. The leaves of Early Prolific Straightneck plants developed vein clearing followed by mottling. Luffa acutangula, 
L. cylindrica, C. melo var. 180280 and Melothria guadalupensis displayed very faint mottling.

No infection was obtained when the following plants were inoculated with the Isabela mosaic virus: Capsicum annum var. Large Bell Hot, Nicotiana glutinosa, Chenopodium amaranticolor, $N$. tabacum var. NN, $N$. silvestris, Phaseolus vulgaris var. Scotia, Vigna sinensis var. Black, Ditremexa occidentalis, Scoparia dulcis, Leucaena glauca, Sicania odorifera, Cajan cajan, Phaseolus lunatus var. Fordhook, Soja max, Dolichos sp., Canavalia sp., Melothria guadalupensis, Phaseolus vulgaris var. Bonita, Gomphrena globosa, Physalis floridana, Phytolacca icosandra, Datura stramonium, Coccinea cordifolia, Althaea rosae, Zinnia elegans, Solanum melongena var. Rosita, Momordica charantia, Aster sp. var. Giant Branching, Cyphomandra betacea, Impatiens balsamina, Spinacea oleracea and Leucaena glabra.

Seed transmission experiments demonstrated that the Isabela mosaic virus is not seed-transmitted. Eight hundred thirty five plants originating from the seed of mosaic-affected plants failed to develop symptoms of mosaic.

The physical properties of the virus are: Thermal inactivation point, $60^{\circ} \mathrm{C}$.; dilution end-point, 1-100. The virus becomes inactive after about 72 hours at laboratory temperature (about $74^{\circ} \mathrm{F}$.). The virus is not transmitted through the soil.

Cross protection tests demonstrated that papaya plants inoculated with the mild Isabela mosaic virus are protected from the more virulent Puerto Rican southern coast papaya mosaic virus. This indicates relationship between the two viruses.

Five of 27 healthy papaya seedlings growing among infected seedlings in the Trichodorus infected pots showed symptoms of Isabela mosaic. The controls remained mosaic-free. This suggests nematode transmission of the Isabela mosaic virus. Further studies are necessary to clarify this point.

All the Carica papaya varieties and selections tested failed to show even minimal resistance to the Isabela mosaic virus. The Hawaiian variety SOLO was found highly susceptible. Experiment Station selections P.R. $8-65$, S-1, S-64, S-7-65, S-9-65, S-6-65 and S-10-65 were infected successfully by mechanical means under greenhouse conditions.

Results of extensive inoculation trials have shown, however, that Carica candamarcensis Hook., a small, edible South American species of papaya, is immune to both Isabela and Puerto Rican southern coast papays mosaic viruses of Puerto Rico (7). This species did not become infected when inoculated by mechanical means or via grafting.

\section{DISCUSSION AND CONCLUSIONS}

The presence of a papaya mosaic virus (Puerto Rican southern coast papaya mosaic virus) was reported from Puerto Rico many years ago by 
Adsuar $(3,4,5)$. The studies reported here indicate the presence in Puerto Rico of another virus essentially similar to the Puerto Rican southern coast papaya mosaic virus in physical and immunological properties, but differing from it in symptomatology. It seems that both these viruses are similar or closely related symptomatologically to the mild mosaic (MM) and distortion ringspot (DR) recently reported by de Bokx (8) from Florida. However, the MM described by de Bokx, although exhibiting symptoms similar to those caused by the Isabela mosaic virus, differs from this virus in physical properties, and also because the MM from Florida produces symptoms on Gomphrena globosa and Chenopodium amaranticolor.

The Isabela mosaic virus is the limiting factor at present in the production of papaya in the northwestern section of the Island. The problem in this area is complicated further by the Puerto Rican southern coast papaya mosaic virus which has been found occurring in mixed infection with the Isabela mosaic virus.

The Isabela mosaic virus is transmitted non-persistently by several species of aphids. Judging by our experience with the aphid-transmitted Puerto Rican southern coast papaya mosaic virus, it would appear that the Isabela mosaic may be difficult to control by means of insecticides. Perhaps oil sprays such as employed by Loebenstein et al. (9) might be helpful.

Another avenue of approach in the control of the papaya mosaic viruses might be the use of the species Carica candamarcensis Hook. (7) either as a commercial crop or as a source of resistance for both the Isabela and Puerto Rican southern coast papaya mosaic viruses.

\section{SUMMARY}

1. A mosaic virus disease of papaya (Carica papaya) causing yellow mottling, slight wrinkleness of the leaves, and oily spots on the stem but no extreme distortion and deformation of the leaves has been observed in the northwestcrn part of Puerto Rico near the town of Isabela.

2. The physical properties of the virus are: Thermal inactivation point, $60^{\circ} \mathrm{C}$.; dilution end-point, 1-100; and it is inactivated in about 72 hours at laboratory temperature (around $74^{\circ} \mathrm{F}$.). The virus is not seed- nor soil-transmitted.

3. The virus has been transmitted mechanically thus far only to members of the family Cucurbitaceae belonging to the following genera: Cucumis, Luffa, Citrullus, Lagenaria and Melothria. It has not been possible to transmit the virus to plants of the following families: Solanaceae, Amaranthaceae, Phytolacaceae, Malvaceae, Balsaminaceae, Leguminoseae, Scrophulariaceae, Mimosaceae, and Cesalpinaceae.

4. Cross-protection tests have demonstrated that the Isabela mosaic and the Puerto Rican southern coast papaya mosaic viruses are related. 
5. Preliminary experiments indicate that the Isabela mosaic virus may be transmitted by the nematode Trichodorus christiei.

6. The results of extensive inoculation trials have shown that Carica candamarcensis Hook. is resistant to the Isabela mosaic virus.

\section{RESUMEN}

1. Se informa la aparición de un nuevo virus atacando la papaya en la región noroeste de Puerto Rico, en los alrededores del pueblo de Isabela.

2. Las propiedades físicas del virus son las siguientes: Inactivación por calor, $60^{\circ} \mathrm{C}$.; límite de dilución, 1-100; longevidad a temperatura de laboratorio ( $74^{\circ} \mathrm{F}$ ), 72 horas. El virus no se transmite ni por la semilla ni por el terreno.

3. Se ha logrado transmitir el virus a los siguientes géneros de la familia de las cucurbitaceas: Cucumis, Luffa, Citrullus, Lagenaria y Melothria. El virus no ha podido transmitirse a plantas de las siguientes familias: Solanaceas, Amarantaceas, Fitolacaceas, Malváceas, Balsaminaceas, Leguminosas, Escrofulariaceas, Mimosáceas y Cesalpináceas.

4. Pruebas de interferencia entre el virus de Isabela y el que causa el mosaico de la papaya en la costa sur de Puerto Rico demuestran que ambos virus están relacionados.

5. Ensayos preliminares llevados a cabo en el invernadero sugieren que el nemátodo Trichodorus christiei puede transmitir el virus causante del mosaico de Isabela.

6. Se ha comprobado en pruebas de invernadero que la especie de papaya Carica candamarcensis Hook es altamente resistente al virus que causa el mosaico de la papaya de Isabela.

\section{LITERATURE CITED}

1. Story, G. E., and Halliwell, R. S., Association of a mycoplasma-like organism with the bunchy top disease of papaya, Phytopathology 59(9): 1336-7, 1969.

2. Adsuar, J., Transmission of papaya bunchy top by a leafhopper of the genus Empoasca, Science 103: 316, 1946.

3. - Studies on virus diseases of papaya (Carica papaya) in Puerto Rico. I. Transmission of papaya mosaic, Agr. Exp. Sta., Univ. P.R. Tech. Paper 1, 10 pp., 1946.

4. - Studies on virus diseases of papaya (Carica papaya) in Puerto Rico. II. Transmission of papaya mosaic by the green citrus aphid (Aphis spiraecola Patch), Agr. Exp. Sta., Univ. P.R. Tech Paper 2, 5 pp., 1946.

5. - Studies on the virus diseases of papaya (Carica papaya) in Puerto Rico. IIl. Property studies of papaya mosaic virus, Agr. Exp. Sta., Univ. P.R. Tech. Paper 4, 11 pp., 1946.

6. Schaefers, G. A., Aphid vectors of the papaya mosaic viruses in Puerto Rico, J. Agr. Univ. P.R. 53(1): 1-13, 1969.

7. Adsuar, J., Resistance of Carica candamarcensis Hook to the mosaic viruses affecting papayas (Carica papaya) in Puerto Rico, J. Agr. Univ. P.R. 55(2): 265-6, 1971.

8. de Bokx, J. A., Host and electron microscopy of two papaya viruses, Plant Dis. Reptr. 49(9): 742-6, 1965.

9. Loebenstein, G., Alper, M., and Levy, S., Field tests with oil sprays for the prevention of aphid-spread viruses in peppers, Phytopathology $60(2): 212-6$, 1970. 